\title{
Study the Acute \& Sub Acute Toxicity of Ricinus cummunis Lnn. Ethanol Extract of Seed in Albino Mice
}

\author{
Manal H. AL-Jborrey, Muastafa A. K. Altaie, Ayyad W. Al-Shahwany \\ College of science, University of Baghdad, Iraq
}

\begin{abstract}
Background: Toxicity still a global problem for the environment, agriculture and ultimately human health.

Objective: In this study attempt to investigate the toxicological profile of the ethanol, extract of Ricinus cummunis after acute and sub-chronic administration to mice.

Methods: In the acute toxicity study, a single administration of the extract at doses of $1000,2000,3000,4000$ and $5000 \mathrm{mg} / \mathrm{kg}$, respectively, was gave orally. Mice were observed for general behavioral changes, adverse effects and mortality up to 10 days post-treatment. In sub-acute toxicity studies, herbal extract was gave orally to mice at doses of $50 \mathrm{mg} / \mathrm{kg}, 100 \mathrm{mg} / \mathrm{kg}$ and $150 \mathrm{mg} / \mathrm{kg}$ for 10 days.

Results: In the acute toxicity study, the mortality appeared in $2000 \mathrm{mg} / \mathrm{kg}$ and LD50 were calculated at $1100 \mathrm{mg} / \mathrm{kg}$. In the sub-chronic toxicity the study show significant differences in body weight between the control and treated groups $(p<0.05)$. Histopathology of vital organ (liver \& kidney) show morphological changes.

Conclusions: These results demonstrate the real toxic effect of the ethanolic extract after single dose. The LD50 value is $1100 \mathrm{mg} / \mathrm{kg}$ and research indicates that successive use of the seed at the dose above $(2 \mathrm{~g} / \mathrm{kg}$ in human) daily for long period may cause toxic signs.

Highlights: The Ricinus communis oil's has wide variety of industrial applications: as a drying oil for paints, varnishes, plastics and resins is an ingredient in numerous cosmetics. But it need to toxicity study as acute and sub-acute with observation of hematological and histopathological to be more safety for used.
\end{abstract}

Keywords: Ricinus communis; LD50; sub-chronic toxicity; hematological parameter and histopathological changes.

\section{Introduction}

The Ricinus communis; which has different names like castor oil herb or Palma(e) Christi or wonder tree s, it belong to Euphorbiaceae family [1,2]. Ricinus communis herb may be originates from Africa and in ancient times the herb used in Egypt or Romans and Greeks; now the herb grows wildly in many tropical and subtropical regions around the world [3-6]. R. communis has a variety of pharmacological actions due it chemical constitutions like Ricin A, B and C which have antitumor action, alkaloid (ricinine) and glycoside, which may be use full for various herbal formulation as anti-inflammatory, analgesic, antipyretic, cardiac tonic and antiasthamatic etc. [7]. In Saudi Arabia and India, they eat seed of $R$. communis on the first day of menstruation as oral contraceptive. The seeds contain about 30-35\% oil. Oil can be extracted by different processes such as, cold press and solvent extraction [8]. Oil has highest viscosities among vegetable oils, with a molecular weight of $298 \mathrm{mg}$ and naturally occurring triglycerides with a high ricinolin content(a glyceride of 12 hydroxy-9-octadecenoic acid), and has the approximate fatty acid composition of ricinoleic acid (87\%), Oleic acid (7\%), linoleic acid (3\%), palmitic acid (2\%), stearic acid $(1 \%)$, with trace amounts of dihydroxystearic acid [9,10]. The seeds oil has been used for medical purposes as laxative; for treatment of infection and inflammation [1]. The oil seeds after extraction considered a rich 
source of protein and can be used as supplement feed to different animals' sheep, cattle and chicken [1117] but the use was limited due to the toxicity of ricin [18].

The castor oil's has the ability to heal wounds and cure ailments, bactericide, purgative, insecticide, larvicidal, sunburn, treatment of warts, cold tumors' indurations of the mammary glands [19]. The seeds oil has wide variety of industrial applications: as a drying oil for paints, varnishes, plastics and resins is an ingredient in numerous cosmetics [20].The aim of this research was to study the acute and sub-acute toxicity of Ricinus communis L. extract with observation of hematological and histopathological changes in albino mice.

\section{Materials and Methods}

Collection of Samples: the seeds of (Ricinus communis) were collected from Baghdad local market.

\section{Preparation of herbal extract of seed}

$100 \mathrm{~g}$ of plant powder was homogenized in electrical blender with $350 \mathrm{ml}$ of (4:1) ethanol: D.W. the sample was filter by muslin and with filter paper in bouknner funnel then acidified by drops of (2\% sulphuric acid) until the $\mathrm{pH}$ become 1-2. The solution was re-extracted with chloroform 3 time in the suppuration funnel until seen 2 layer; the upper on was neglected while, the lower layer used. Drops of concentrated ammonium hydroxide added to solution until the $\mathrm{pH}$ was "between 9 to 10". The solution again extracted with chloroform: methanol 1:3. Then the solution separated to two layer; the lower layer was taken and evaporated with rotary evaporated at $40 \mathrm{C}^{\circ}$ for $1-2 \mathrm{hr}$. Then the extract dried in oven at $40 \mathrm{C}^{\circ}$ until it turn to powder then kept in refrigerator until used [21,22].

\section{Experimental Animals}

Forty adult white albino mice (male and female) non-pregnant weighing between $(20-25 \mathrm{~g}$ ) were used for acute and sub acute toxicity test kept in animal house of Alrazi center under laboratory condition of 25-28 ${ }^{\circ} \mathrm{C}$, and supplied food and water for the period of research. Fifty albino mice were used for acute and subchronic toxicity study. The study has been done as a joint collaboration between a Master's student and an internship team of Veterinary Drug Center, Baghdad, Iraq; were produced and approved the experimental protocol of the study. All animals used once for ethical reasons. Then all animals weresacrificed at the end of the study for pathological changes and blood parameter test [4].

\section{Experimental Design}

In acute toxicity study, the ethanol extract of castor seed were determined and the groups of albino mice were divided into six groups (I, II, III, IV, V and VI) each group contain five mice; all groups were administered orally at dose 1000, 2000, 3000, 4000 and $5000 \mathrm{mg} / \mathrm{kg}$. All animals were observed after treatment for 24 hours and the number of death recorded, if any. Also the observed remained to 14 day for any sign of delayed toxicity as described by Lorke [10]. In sub chronic toxicity study, twenty albino mice were grouped into four mice each, randomly assigned to four cages labeled I, II, III, and IV, respectively. All cages kept at room temperature (25-28 C $)$. All the mice were allowed free access to water and feed for a 10 days to acclimatize them to laboratory conditions; the control animals (group I) Were given distilled water orally while other groups II, III, and IV were given orally $50 \mathrm{mg} / \mathrm{kg}, 100 \mathrm{mg} / \mathrm{kg}$ and $150 \mathrm{mg} / \mathrm{kg}$ respectively. At the end of the 10 days of oral administration of ethanol seed extract of Ricinus communis, the mice were sacrificed.

\section{Hematological parameter}

Blood samples were taken directly from punch heart and collected in clean and dried EDTA. Tube was used for the analysis of hematological parameters such as hemoglobin, red blood cell count, white blood cell count and PCV. 


\section{Histopathology}

All the animals were euthanized for gross pathological examinations of all major internal organs. Organs such as liver and kidney were collected from the animals for histopathology. The collected organs were weighed and preserved in $10 \%$ neutral buffered formalin, trimmed and a $5 \mu$ thickness of tissue sections was stained with hematoxylin and eosin for histopathological study.

\section{Statistical analysis}

Results are expressed as mean \pm SEM. A probability value of $\mathrm{p}<0.05$ was considered statistically significant.

\section{Results/Discussion}

\section{Acute toxicity studies:}

Oral administration of the extract at dose 1000, 2000, 3000, 4000 and $5000 \mathrm{mg} / \mathrm{kg}$ produce differ clinical signs and mortality of mice start at dose $2000 \mathrm{mg} / \mathrm{kg}$, LD50 value of caster seed ethanol extract was found to be $1100 \mathrm{mg} / \mathrm{kg}$ as in shown in table 1 .

\section{Sub acute toxicity studies}

There were no signs or mortality observed in both sexes of mice after treated with caster seed ethanol extract at $50 \mathrm{mg} / \mathrm{kg}, 100 \mathrm{mg} / \mathrm{kg}$ and $150 \mathrm{mg} / \mathrm{kg}$ during the 10 days of treatment as in shown in table 2 .

\section{Body weight changes}

Body weight considered as an important factor to monitor the health of an animal so loss in body weight was frequently the first indication of the onset of adverse effect and the dose. Table 2 showed that, there were significant differences in body weight between the initial and final body weight with control treatment, which causes $16 \%$ increase in the body weight.

\section{Hematological parameter}

The hematological profile of treated and control group are summarized in Table 1. All hematological parameters such as total red blood cell count, total white blood cell count and hemoglobin all value at normal level; PCV showed increase during the experimental period.

Table 1: the Ricinus communis ethanolic extract given orally to determine the acute toxicity LD50 in mice

\begin{tabular}{|c|c|c|c|c|c|c|}
\hline $\begin{array}{c}\text { Grou } \\
\text { p }\end{array}$ & $\begin{array}{c}\text { Dose } \\
(\mathrm{mg} / \mathrm{kg})\end{array}$ & $\begin{array}{c}\text { Dose } \\
\text { difference } \\
(\mathrm{mg} / \mathrm{kg})\end{array}$ & $\begin{array}{l}\text { No. o f } \\
\text { Anima } \\
\text { l per } \\
\text { group }\end{array}$ & $\begin{array}{l}\text { No. of } \\
\text { Dea } \\
\text { d } \\
\text { mice }\end{array}$ & $\begin{array}{l}\text { Mean of } \\
\text { dead }\end{array}$ & $\begin{array}{l}\text { Dose } \\
\text { difference } \\
\text { X } \\
\text { mean } \\
\text { Dead }\end{array}$ \\
\hline I & control & - & 5 & 0 & 0 & 0 \\
\hline II & $1000 \mathrm{mg} / \mathrm{kg}$ & 1000 & 5 & 0 & 0 & 0 \\
\hline III & $2000 \mathrm{mg} / \mathrm{kg}$ & 1000 & 5 & $1 / 5$ & 0.5 & 500 \\
\hline IV & $3000 \mathrm{mg} / \mathrm{kg}$ & 1000 & 5 & $2 / 5$ & 1.5 & 1500 \\
\hline $\mathrm{V}$ & $4000 \mathrm{mg} / \mathrm{kg}$ & 1000 & 5 & $3 / 5$ & 2.5 & 2500 \\
\hline VI & $5000 \mathrm{mg} / \mathrm{kg}$ & 1000 & 5 & $5 / 5$ & 4 & 4000 \\
\hline \multicolumn{7}{|c|}{$\begin{array}{l}\text { LD50 }(\text { Ricinus communis) oil extract }=3000-8500 / 5=1100 \mathrm{mg} / \mathrm{kg} \\
\text { Sum }=8500\end{array}$} \\
\hline
\end{tabular}

Table (2) Body weight changes of mice after given $R$. communis oily extract orally for 10 days.

\begin{tabular}{|c|c|c|c|c|}
\hline \multirow{2}{*}{ Day } & \multicolumn{4}{|c|}{ Daily dose for 5 mice in each group } \\
\cline { 2 - 5 } & Control & $\mathbf{5 0} \mathrm{mg} / \mathbf{k g}$ & $100 \mathrm{mg} / \mathrm{kg}$ & $150 \mathrm{mg} / \mathrm{kg}$ \\
\hline 1. & 30 & 30 & 34.5 & 34.5 \\
\hline 2. & 30.1 & 30 & 35 & 33 \\
\hline 3. & 30.1 & 31 & 36.9 & 33 \\
\hline
\end{tabular}




\begin{tabular}{|c|c|c|c|c|}
\hline 4. & 30.2 & 33 & 37.8 & 32.6 \\
\hline 5. & 30.2 & 33.7 & 39.5 & 32.6 \\
\hline 6. & 30.4 & 28 & 35.5 & 35.6 \\
\hline 7. & 30.4 & 28.4 & 35.2 & 34.4 \\
\hline 8. & 30.3 & 25.5 & 33 & 34 \\
\hline 9. & 30.5 & 27 & 35 & 35.5 \\
\hline 10. & 30.5 & 29 & 35 & 34 \\
\hline M.S.D & $30.27 \pm 2.11$ & $\begin{array}{c}29.56 \pm \\
2.55\end{array}$ & $35.75 \pm 1.83$ & $33.92 \pm 1.10$ \\
\hline
\end{tabular}

Table 3: Hematological parameter of Ricinus communis oily extract given orally to mice for 10 days.

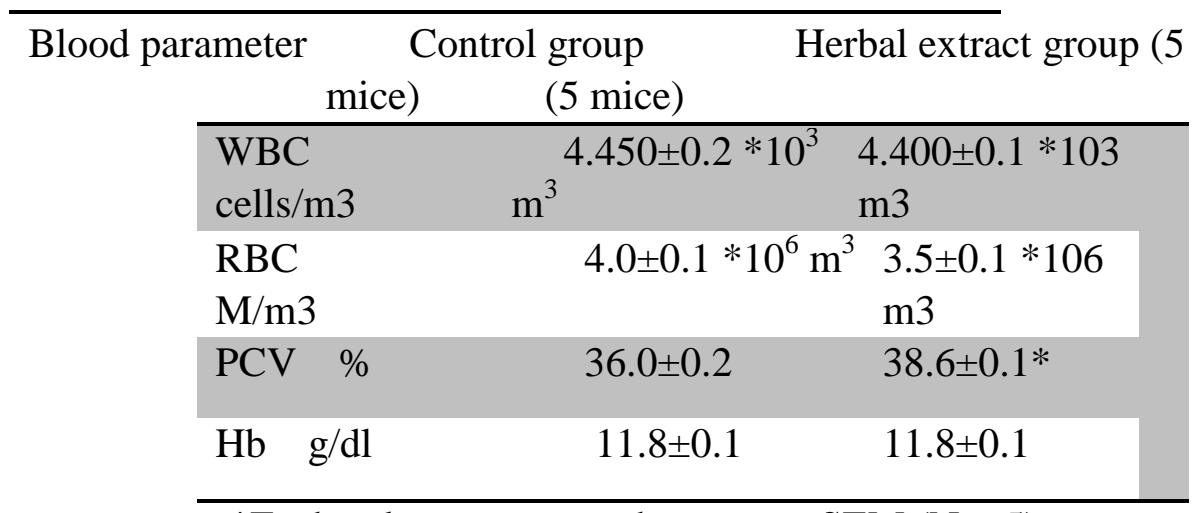

$*$ Each value represents the mean \pm SEM $(\mathrm{N}=5)$

\section{Histopathological analysis}

The liver section (figure 1,2) show congestion blood vessels and infiltration of inflammatory cells mainly monocyte in dose 50 and $100 \mathrm{mg} / \mathrm{kg}$; presence of mitotic figure with focal aggregation of mononuclear cells in dose $150 \mathrm{mg} / \mathrm{kg}$. While, kidney section (figure 3, 4, 5,6) shows congestion and hyaline casts in urinary tubules, which extended to glomeruli treated group tissue received high dose. 
Histopathological Examination:

In liver
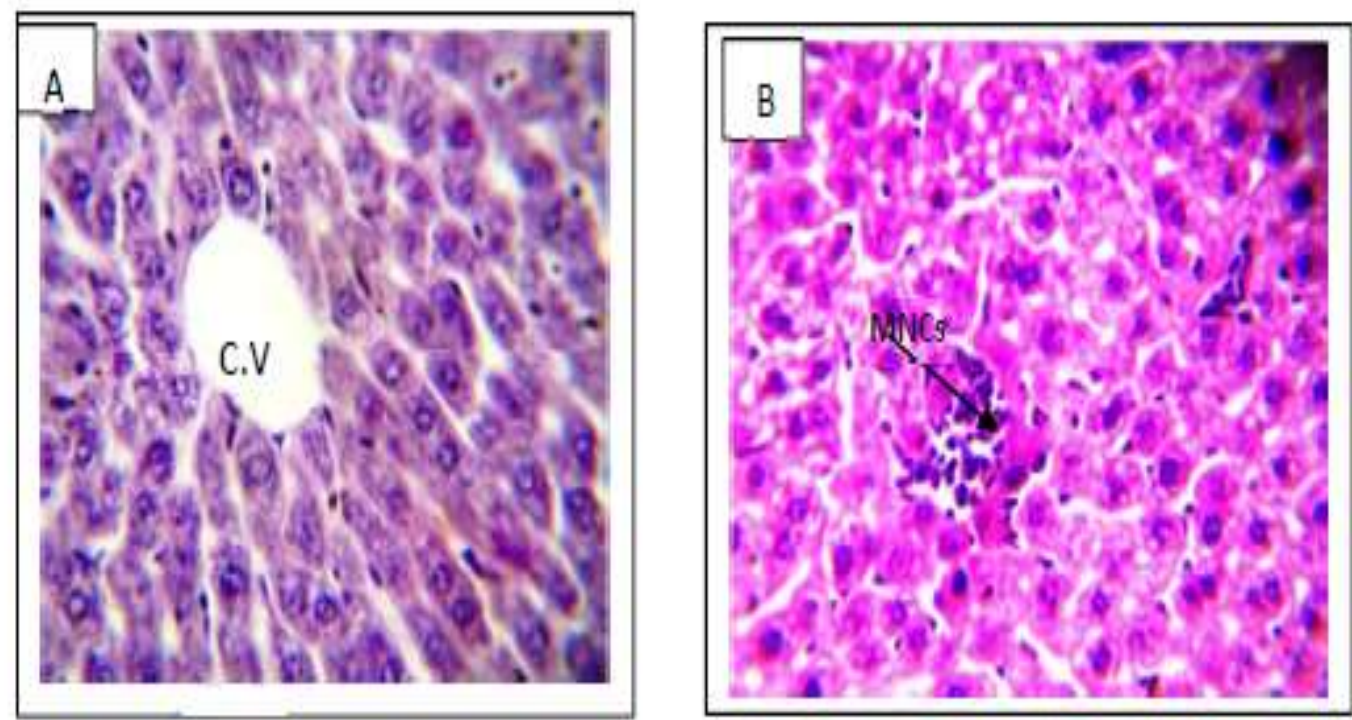

Figurel: Microscopir section in liver of mice treated with 50 (A) and 100 (B) mg kgb.w of Ricimus communis ethanol extract H $W E$ stain X40)
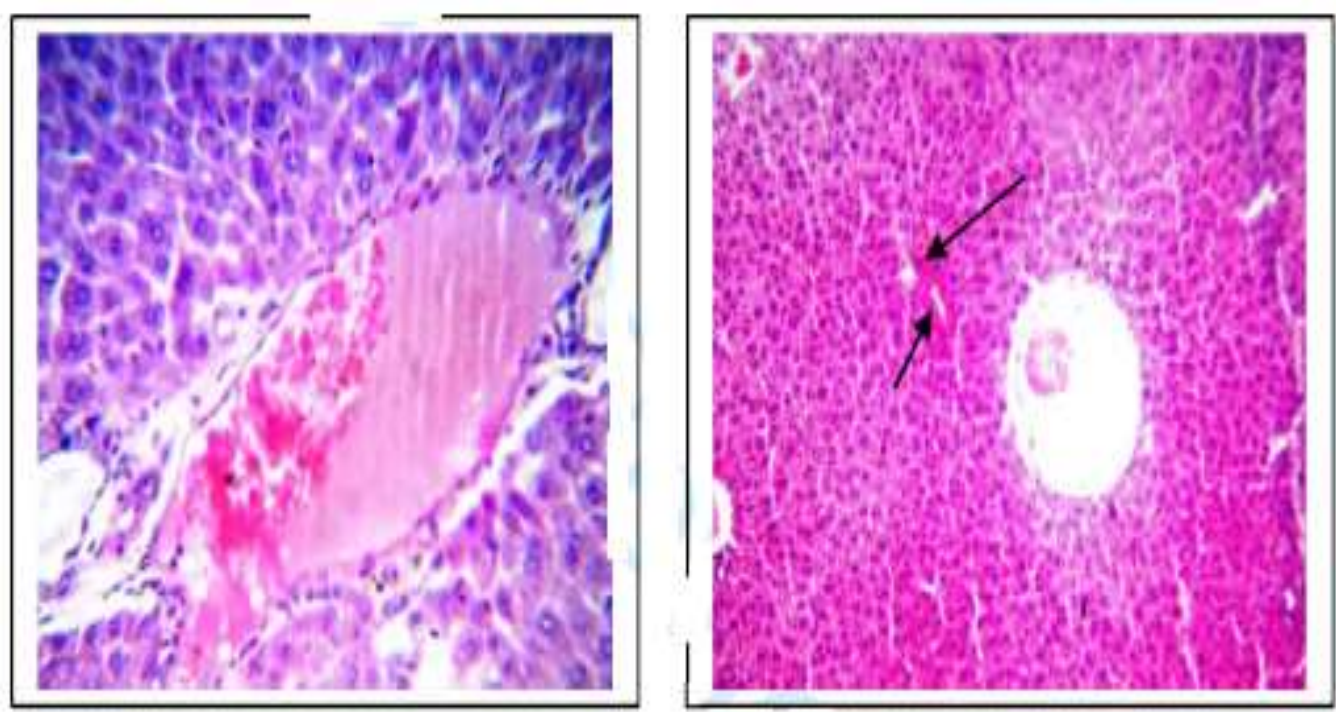

Figure2: Microscopic section in liver of mice treated with $150 \mathrm{mg} \mathrm{kgb} . \mathrm{w}$ of Ricinus communis ethanol extract $(\mathrm{H} \& \mathrm{E} \operatorname{stain} \mathrm{X} 40)$

Figure: 1 And 2 


\section{In kidney}

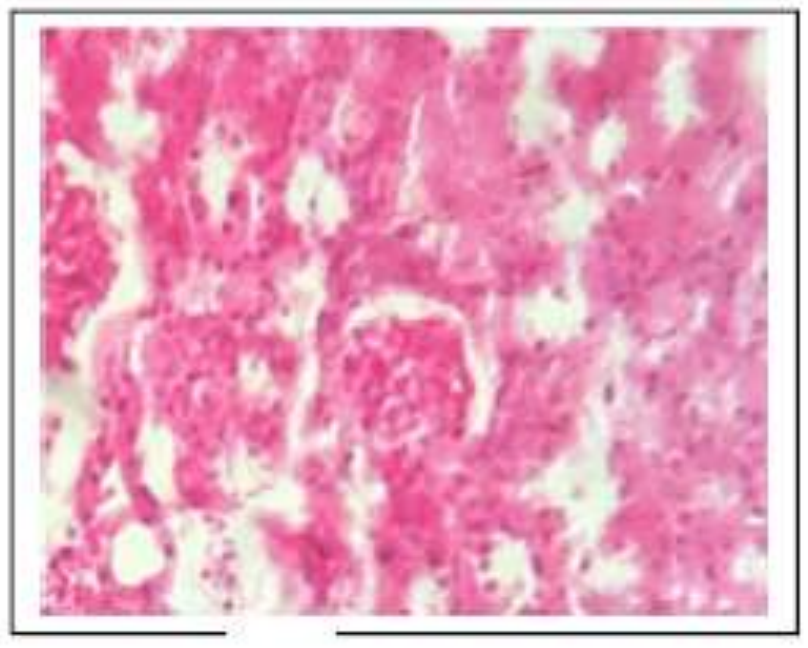

Figure 3 : Microscopic section of control liduey with mornal architecture (H\&F stain X49)

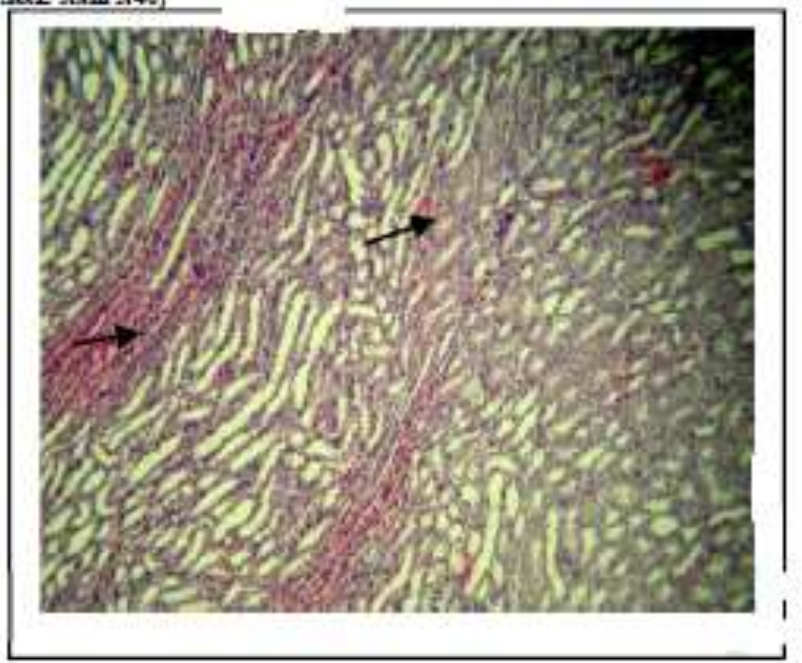

Figure 5: Microscopic section in kidney with dose $100 \mathrm{mg} / \mathrm{kg}$ (H\&E stain X40)

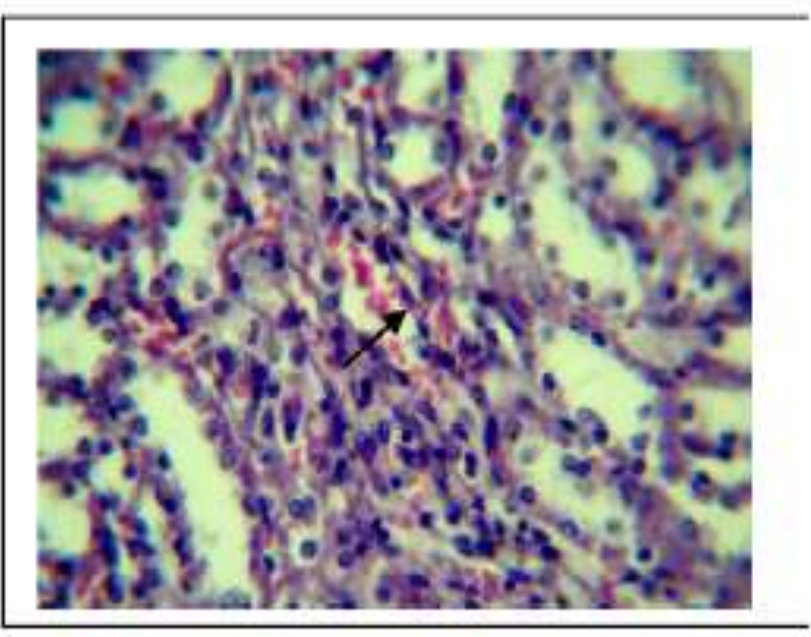

Figere 4: Microscopic section in lidney with dose $50 \mathrm{mg} / \mathrm{kg}$ (ER\& stain X)

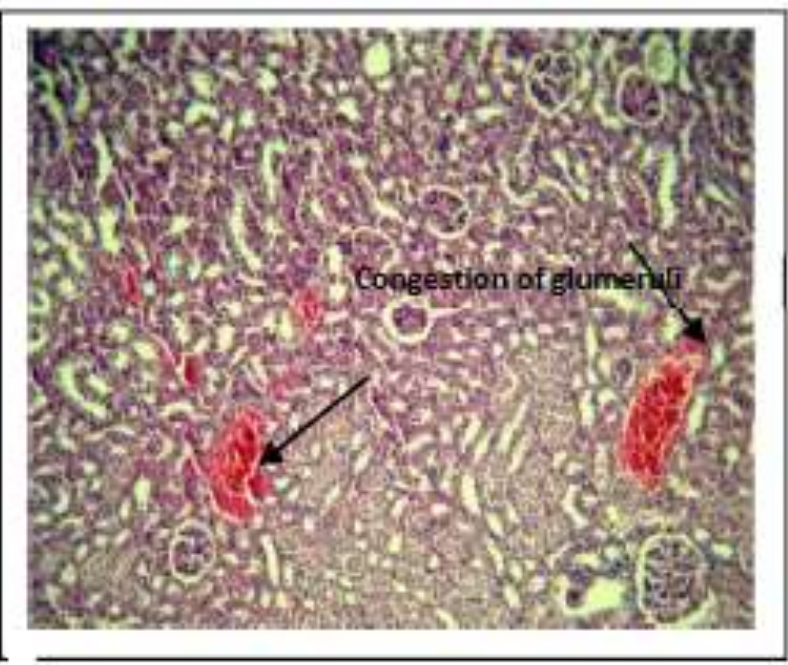

Figure 6: Mficroscopic section in kidney xith dose $150 \mathrm{mg} / \mathrm{kg}$ (H\&E stain $\mathrm{X40}$ )

Figure: 3,4,5and 6

\section{Discussion}

In the current study, it was found that mice treated with $1000,2000,3000,4000$ and $5000 \mathrm{mg} / \mathrm{kg}$ body weight/day. Acute toxicity test of ethanolic extract of caster seed produce toxic effect, morbidity or mortality were observed in $2000 \mathrm{mg} / \mathrm{kg} \mathrm{B}$.W. of mice with multiple behavioral changes like reduction of motor activity, sedation, asthenia, grooming and difficult to breathe after 2 hours of the administration of extract. In addition, there were signs of respiratory distress, muscle paralysis after 8 hours of treatment [23, 24]. After 24 hours all groups of mice showed mortality except the first groups compared to control one and the reduction in the activity and behavioral changes of the mice was very quickly appear mainly in higher doses of the extract may be due to method of extraction [25]. This finding, therefore, suggests that the ethanolic extract at dose higher than $1000 \mathrm{mg} / \mathrm{kg}$ is essentially toxic and has different toxic effect after oral administration. Finally the (LD50) of extract was $1100 \mathrm{mg} / \mathrm{kg}$ body weight. The sub-acute dose was selected dose based lower than LD50 value which kept mice alive, i.e. 50, 100 and $150 \mathrm{mg} / \mathrm{kg}$ repeated for 10 days, which given orally to report the toxicity signs in mice and body weight changes. There were no signs of toxic and death observed in all groups of animals. The body weight gain after treated with 50 $\mathrm{mg} / \mathrm{kg}$ body weight/day extract group was statistically no significant, while 100 and $150 \mathrm{mg} / \mathrm{kg}$ body weight/day were significant $(\mathrm{p}<0.05)$ increased compare with control group . That gain of body weight may be due to protein present in seeds which, dissolved in extract [26], or may contain compounds which 
increase the appetite, especially in high doses [27, 28]. However, since when there was dally weight gain, the extract could be claimed non-toxic to the animals [29, 30]. The organ weight considered as important indicator of physiological and pathological status of animals or fundamental to confirm whether the organ was exposed to the injury or not mainly liver and kidney. Those organs primarily affected by metabolic reaction caused by toxicant [31]. Hematological results (table 3) showed no significant change in the RBC count, WBC and $\mathrm{Hb}$ in treated mice, while there was significant changed in PCV as compared to control group, and hematological value good indication for toxicity and a blood outline was major information of reaction the body with damage [32]. The increased in the PCV values which suggests valuable effect on erythropoiesis process or bone regeneration activity and this emerge the protective role of $R$. communis extract [33]. The slight reduction in WBC count may be due to affect function of immune systems and could claimed that extract non-toxic to immune systems [34]. Histopathological examination of organs (liver and kidney) of treated groups showed sign of toxicity. The liver section show congestion of blood vessels could attributed to its role in biotransformation of xenobiotic. Infiltration of inflammatory cells mainly monocyte at 50 and $100 \mathrm{mg} / \mathrm{kg}$ body weight respectively may be extract exerted a deleterious effect in high doses [35], or could be considered a sign of injury or sign of inflammation cause by foreign body exposed to internal tissue[36]. The liver didn't show serious signs of injury so it can regenerating damage may be presence of flavonoid [37], potent antioxidant in $R$. communis which provide possible protection effect to liver cell against any toxicity and reduced injury[38]. The histological changes in the kidney of the treated groups showed congestion of renal tissues. This may due to the kidney is an excretory organ and the main job was remove metabolise and non-metabolised material from the body,so it could be exposed to high concentrations of toxic materials that could cause lesions or disorder in interstitial tissue after prolong treatment[39]. In kidney section of treated groups show atrophied in some convoluted tubules with tubular cast that was agreed with result of [40], that may be metabolic disturbance [41].

The high concentration of extract may be concentrated in blood which lead to accumulated in basement membrane of kidney for long period converted to haylin cast or tubular cast might cause obstruction of tubular lumen lead to decrease glumeruler infiltration and that may cause respectively minimizes the toxic effect of extract. finally all result may pressed shrinkage or atrophy of glumeruli and injury of flattened epithelium tissue of renal tubules by way lead to hemmorage and disruption of tubular basement membrane lead to inflammatory reaction [42].

\section{Conclusion}

In the study it has been concluded the ethanol extract of ricinus which used as medicinal plant can cause different sign of toxicity or damage can emerge after prolong use.

The world of herb is wide spectrum world and knowledge of its secrets needs a lot of time and effort. With all the despite and obstacles facing researchers in this area, we note the high vigor in the search for any new information added to the advantages and importance of herbal information. The study considered as complementary to other studies may add something to that herb knowing the toxic effects of the herbal extract on animal through study tissue and linked to effect of herbal extract on blood parameter which mean study the direct effect and non-direct effect a real human health.

\section{Acknowledgements}

Full thanks to allah the Director who enabled us to complete the work. To staff of the Animal House, in particular Dr.maan and Dr.thurea for all helpful and to any member who contributed to the completion of the work.

\section{Reference:}

[1] Shah T. I, Sharma E. and Shah G.A(2015) . International Journal of Recent Scientific R.;6 (3): 2886-2889.

[2] Worbs S. , Köhler K. , Pauly D., Avondet M., Schaer M., Dorner M.B and Dorner B.G (2011) Toxins J.; 3:1332-1372.

[3] Faisal A. AL-Tamimi F. A and Hegazi A. E (2008) Sultan Qaboos Univ Med J. 2008 Mar; 8(1): 8387.

[4] Scarpa A.; Guerci, A. (1982) J. Ethnopharmacol. 5, 117-137. 
Serpico, M., White, R. (2000) Oil, Fat and Wax. in Ancient Egyptian Materials and Technology; Nicholson, P.T., Shaw, I., Eds.; Cambridge University Press: Cambridge, UK,; pp. 3906.

[6] Weiss, E. A. (2000) Oilseed Crops, 2nd ed.; Blackwell Science Ltd.: Oxford, UK. pp. 428.

[7] Khan A. and Sanwal M. (2017) Medicinal Importance of Ricinus communis (A randi). Institute of Biomedical Sciences \& Research, Dehradun, India;1:1-5.

[8] Salunke D.K., Desai B.B.,(1992). CRC Press, p.161- 170.

[9] Kulkarni, M. G. and Sawant, S. B. (2003) Eur. J. Lipids and Sci. Technol. 105:214-218.

[10] Windholz M. (ed.) (1976) The Merck Index, 9th Edition. Rahway, NJ: Merck \& Co., Inc., p. 242.

[11] Behl C. R.; Pande, M. B.; Pande, D. P.; Radadia, M. S. (1986) Indian J. Anim. Sci.; 56: 473- 474.

[12] Robb, J.G.; Laben, R.C.; Walker, H.G., Jr.; Herring, V. (1974) J. Dairy Sci.; 57: 443-450.

[13] Gowda, N.K.S., Pal, D.T., Bellur, S.R., Bharadwaj, U., Sridhar, M., Satyanarayana, M.L., Prasad, C.S., Ramachandra, K.S., Sampath, K.T. (2009) J. Sci. Food Agric. 89: 216-220.

[14] Balogun, J.K., Auta, J., Abdullahi, S.A., Agboola, O.E. (2005) In Proceedings of the 19th Annual Conference Fisheries Society Nigeria, Ilorin, Nigeria; 1: 838-843.

[15] Diniz, L.L., Valadares Filho, S.C., De Oliveira, A.S., Pina, D.S., de Lima da Silva, N., Benedeti, P.B., Baião, G.F., Campos, J.M.S., Valadares, R.F.D. (2011) Livest. Sci., 135: 153-167.

[16] Ani, A.O. (2007) J. Trop. Agric. Food Environ. Ext. ; 6: 89-97.

[17] Tangl, H. (1939) Kiserletuegyi Koezlemenyek J. ;41: 69-72.

[18] Final report on the safety assessment of Ricinus communis (castor) seed oil, hydrogenated castor oil, glyceryl ricinoleate, glyceryl ricinoleate se, ricinoleic acid, potassium ricinoleate, sodium ricinoleate, zinc ricinoleate, cetyl ricinoleate, ethyl ricinoleate, glycol ricinoleate, isopropyl ricinoleate, methyl ricinoleate, and octyldodecyl ricinoleate .(2007) Int. J. Toxicol.; 26: 31-77.

[19] Gibbs S., Harvey I., Sterling J. and Stark R. (2002) B.M. J. 352(7362): 461-464.

[20] Robb, J.G., Laben, R.C., Walker, H.G., Jr., Herring, V. (1974) J. Dairy Sci.; 57: 443-450.

[21] Harborne, J.B., Baxter, H. \& Moss, G.P. (1997) Dictionary of Plant Toxins. Chichester: John Wiley \& Sons.

[22] Mawela K.G, Luseba D., Magano S. and Eloff J.N (2010). University of Pretoria J. ;1:1-118.

[23] Irwin, R. (1992). National Toxicology J.; 1:1-5.

[24] Tully R.E and Harry B. (1976). Plant Physiol. J.; 58: 710-716.

[25] Ammatanda M.N (1999) Science J. ;1:1-20.

[26] Draft A. (2015). European Medicines Agency J.;(1):1-52.

[27] Avecina A. (1992) Ghanoon in Medicine. Tehran: Soroush Co; 1-5.

[28] Nematy M., Kamgar M., Mohajeri S.M, Zadeh S.A.T, Jomezadeh M.R, Hasani O.A, Kamali N., Vojouhi S., Baghban S., Aghaei A., Soukhtanloo M., Hosseini M., Gholamnezhad Z., Rakhshandeh H., Norouzy A., Habibollah E., Majid G. and Michael P.(2013). Avicenna J Phytomed . Vol 3(1): 9197.

[29] Alexander J., Benford D., Cockburn A., Cravedi J., Dogliotti E, Di Domenico A., Férnandez-Cruz M.L, Fürst P., Fink-Gremmels J., Galli C.L, Grandjean P., Gzyl J., Heinemeyer G., Johansson N, Mutti A., Schlatter J., van Leeuwen R., Peteghem C., Philippe V. (2008) .The EFSA J.; 726: 1-38.

[30] Amna O.F, Nooraain H., Noriham A., Azizah A. H and Husna R. N (2013) International Journal of Bioscience, Biochemistry and Bioinformatics, Vol. 3, No. 4:301-305.

[31] Dybing E, Doe J, Groten J, Kleiner J, O’Brien, J. (2002). Food Chem. Toxicol. ; 42: 237-282.

[32] Tao Yuan, Wen-Bin Fan, Yu Cong, Hai Dong Xu,Cheng-Jun Li, Jia Meng,Ni-Rong Bao and JianNing Zhao(2015) Int J Clin Exp Pathol.; 8(5): 5044-5052.

[33] Richard Irwin (1992) National Toxicology J.; 1(1):36.

[34] Bowman W.C and Rand M.J (1982) Text Book of Pharmacology, Blackwell Oxford: Scientific Publications;(1):568-579.

[35] Adebiyi O.E and Abatan M.O(2013) Interdiscip Toxicol.; 6(3): 145-151.

[36] Katherine J Brempelis J.K and Crispe I.N (2016) Clin Transl Immunology ; 5(11): 1113.

[37] Cherish I. Alugah and Omodele Ibraheem (2014) International Journal of Herbal Medicine; 2 (2): 6876.

[38] Nusaibah A., Marwa H. K., Silva A. Y. and Noor N. B.(2013) Journal of Al Nahrain University Vol.16 (2), July:151-156 . 
[39] Mhammad H.A, Saleh Jubrail A.M and Najeeb .KM(2015) International Journal of Chemical and Biomolecular Science.Vol. 1, No. 4, 2015, pp. 248-254

[40] Hathaway GJ, Fischman M.L and Proctor NH(1991) proctor and hughes chemical hazards of the workplace 3rd. new yourk,NY:van nostrand reinhold.

[41] Casarett L and Doull J (1975) toxicology : the basic science of poisons .New York,Toronto,London;1:468-470 .

[42] Samia M.A, Eman G.E.H ,Abdel-Mawgoud A, Abdel-Sattar M, Helmy A.Z, and Mona A. A. (2009) The Egyptian J. of hospital Medicine ;34:36-56. 